\begin{tabular}{|c|c|}
\hline Title & $\begin{array}{l}\text { Comparison of the enzymatic digestibility of phy sically and chemically pretreated selected line of diploid-Miscanthus } \\
\text { sinensis Shiozuka and triploid-M. } x \text { giganteus }\end{array}$ \\
\hline Author(s) & Hideno, A kihiro; Kawashima, Ayato; A nzoua, Kossonou Guillaume; Y amada, Toshihiko \\
\hline Citation & $\begin{array}{l}\text { Bioresource Technology, 146, 393-399 } \\
\text { https://doi.org/10.1016/.biortech.2013.07.084 }\end{array}$ \\
\hline Issue Date & $2013-10$ \\
\hline Doc URL & http:/hdl.handle.net/2115/53643 \\
\hline Type & article (author version) \\
\hline File Information & Revised Manuscript_Hideno et al.pdf \\
\hline
\end{tabular}

Instructions for use 


\section{Comparison of the enzymatic digestibility of physically and chemically pretreated selected line of diploid- Miscanthus sinensis Shiozuka and triploid-M. xgiganteus}

AUTHOR NAMES Akihiro Hideno ${ }^{\mathrm{a}^{*}}$, Ayato Kawashima ${ }^{\mathrm{b}}$, Kossonou Guillaume Anzoua $^{c}$, Toshihiko Yamada ${ }^{c}$

${ }^{a}$ Senior Research Fellow Center, Ehime University, 3-5-7 Tarumi, Matsuyama, Ehime 790-8566, Japan

${ }^{b}$ Faculty of Agriculture, Ehime University, 3-5-7 Tarumi, Matsuyama, Ehime 790-8566, Japan

${ }^{c}$ Field Science Center for Northern Biosphere, Hokkaido University, Kita 11, Nishi 10, Kita-ku, Sapproro, 060-0811, Japan.

*Corresponding author: Tel.: +81-089-946-9771; Fax: +81-089-946-9980; E-mail: $\underline{\text { a- }}$ hideno@agr.ehime-u.ac.jp 


\section{ABSTRACT}

The diploid Miscanthus sinensis "Shiozuka" which was selected as a high-biomass producing line, and the triploid $M . \times$ giganteus $(\mathrm{M} \times \mathrm{G})$ were treated by ball milling (physical treatment) and alkaline hydrogen peroxide treatment (AHP; chemical treatment), and their structural sugar compositions and enzymatic digestibility were compared. The structural sugar content of Shiozuka was moderate and lower than that of $\mathrm{M} \times \mathrm{G}$. The Klason lignin content of Shiozuka was also lower than that of $\mathrm{M} \times \mathrm{G}$. However, Shiozuka was sensitive to ball milling and AHP treatment; ball milled and AHP-treated Shiozuka had higher enzymatic digestibility than ball milled and AHPtreated $M \times G$. Shiozuka would be promising feedstock to obtain fermentable sugars with low energy consumption. Finally, enzymes for the hydrolysis of chemically treated Miscanthus were isolated from Trichoderma reesei ATCC 66589 and Penicillium pinophilum. The sugar yield could be increased by enzymatic hydrolysis of AHP-treated samples with $\mathrm{NaOH}$ and $\mathrm{H}_{2} \mathrm{O}_{2}$ and the isolated enzymes.

\section{Highlights}

> Miscanthus sinensis "Shiozuka" contained moderate sugar but low lignin contents.

> Shiozuka was more sensitive to physical and chemical treatments than $\mathrm{M} \times \mathrm{G}$.

$>$ Enzymatic digestibilities of the pretreated Shiozuka were higher than those of $\mathrm{M} \times \mathrm{G}$.

>Shiozuka is a promising bioenergy grass cultivar. 
KEYWORDS: Miscanthus; ball milling; alkaline-peroxide treatment; enzymatic hydrolysis; self-prepared cellulase 


\section{Introduction}

The genus Miscathus including M. sinensis called "Susuki”, and M. $\times$ giganteus $(\mathrm{M} \times \mathrm{G})$ (Hodkinson and Renvoize, 2001), are considered to be the bioenergy crops because they are $\mathrm{C} 4$ plants that can fix $\mathrm{CO}_{2}$ in high efficiency at low temperature, and less requirement of fertilizer for cultivation (Lewandowski et al., 2003; Naidu and Long, 2004; Heaton et al., 2010; Anzoua et al., 2011; Clifton-Brown et al., 2011). In particular, $M \times G$, which is a natural sterile allotriploid $(3 n=57)$ from the cross between diploid $M$. sinensis $(2 \mathrm{n}=38)$ and tetraploid $M$. sacchariflorus $(4 \mathrm{n}=76)$, has attracted attention and widespread investigation as a nonfood bioenergy feedstock because of its potential for a huge amount of biomass production, and its ability to maintain high photosynthetic productivity at low temperatures by unlike other $\mathrm{C} 4$ plants in the EU and USA (Heaton et al., 2010; Anzoua et al., 2011; Clifton-Brown et al., 2011). M×G has been commercially used as a biofuel crop of thermal power plants in the EU (Christian et al., 2008). However, $M \times G$ has some limitations, for example, its poorly establishment in cold areas at high latitudes, increased risk of susceptibility to disease because it has only a single genotype and difficulty in breeding for improved characteristics owing to its triploid nature (Stewart et al., 2009).

On the other hand, M. sinensis, which is a parent diploid species of $\mathrm{M} \times \mathrm{G}$, is widespread and has been used for biomass production, traditional houses and buildings, organic fertilizer, and livestock feed for centuries in Japan (Stewart et al., 2009), although these 
applications are very rare now. Recently, $M$. sinensis has attracted interest because it exhibits high productivity in cool regions, such as Hokkaido Prefecture in Japan, although the biomass production depends on the environmental conditions and genotypes. The selection and evaluation of $M$. sinensis as a bioenergy crop in cold areas has been previously performed and three wild grown populations (Matsumae, Akeno, and Shiozuka) were selected as high biomass potential lines (Anzoua et al., 2011). Concretely, the biomass productions based on the dry weights of $M$. sinensis Matsumae, M. sinensis Akeno, and M. sinensis Shiozuka, which were harvested in Sapporo ( $43^{\circ} 04^{\prime}$ $\mathrm{N}, 141^{\circ} 20^{\prime} \mathrm{E}$ ) in 2009 , were $1,622 \pm 692 ; 2,653 \pm 635$; and 2,531 $\pm 561 \mathrm{~g} \mathrm{plant}^{-1}$ year $^{-1}$, respectively (Anzoua et al., 2011). No information is available regarding the chemical compositions, efficiency of pretreatment, and enzymatic digestibility for producing fermentable sugars in the Japanese $M$. sinensis selected line in terms of high -biomass production, although some useful information is available on general $M$. sinensis plants (Brosse et al., 2012; Hodgson et al., 2010; Huang et al., 2012; Kim et al., 2012; Yoshida et al., 2008).

Alkaline hydrogen peroxide (AHP) treatment with a stabilizer has been used as an environmentally friendly method for paper pulp bleaching. Without stabilizer, hydrogen peroxide is decomposed to highly reactive oxygen species (superoxide and hydroxyl radicals) as per the following equation (Gould 1984, 1985; Selig et al., 2009): $\mathrm{H}_{2} \mathrm{O}_{2} \leftrightarrow$ $\mathrm{H}^{+}+\mathrm{HOO}^{-}, \mathrm{H}_{2} \mathrm{O}_{2}+\mathrm{HOO}^{-} \rightarrow \mathrm{HO} \cdot+\mathrm{O}_{2} \cdot{ }^{-}+\mathrm{H}_{2} \mathrm{O}$ 
The $\mathrm{H}_{2} \mathrm{O}_{2}$-derived radicals are thought to contribute to the depolymerization and decomposition of lignin to low-molecule-weight compounds. Hence, AHP treatment without stabilizer has been investigated as a pretreatment for enzymatic hydrolysis of lignocellulosic biomass such as wheat straw, rice straw, sugarcane bagasse, and corn stover (Banerjee et al., 2012; Gould, 1984; Monte et al., 2011; Selig et al., 2009). AHP treatment of $\mathrm{M} \times \mathrm{G}$ has also been previously reported (Huyen et al., 2010; Wang et al., 2010). However, information about the AHP treatment of Miscanthus has not been enough, and there is no information about the AHP treatment of M. sinensis.

Cellulases are key enzymes in the biorefinery process based on sugar platform. The costs of cellulases including the purchase cost of commercial cellulases or their production cost, contribute to a large proportion of the total costs of biorefinery process such as the bioethanol production (Fujimoto et al., 2008). On-site production of cellulases is considered to be a solution for reducing the cost of cellulases, including the purchase cost of and transportation costs for distribution (Fujimoto et al., 2008; Hideno et al., 2012). Trichoderma reesei and its mutant strains have been widely investigated (Zhang et al., 2006) as promising hyper cellulase-producing fungi. However, these strains have been known to have low $\beta$-glucosidase activity with respect to the activity of a cellulose-hydrolyzing enzyme such as cellobiohydrolases (CBHs) (Zhang et al., 2006). Moreover, various enzymes are required for enzymatic hydrolysis of feedstock such as rice straw, Miscanthus sp., since these materials contain not only cellulose but 
also various polysaccharide (ex. xylan, arabinan), which is called hemicellulose and cover cellulose. The supplementation including $\beta$-glucosidase and other enzymes, which have synergy effect with $\mathrm{CBH}$ of $T$. reesei, is required.

In this study, the enzymatic digestibility of physically and chemically pretreated $M$. sinensis Shiozuka and $\mathrm{M} \times \mathrm{G}$ were compared to uncover the possibility of using $M$. sinensis Shiozuka as material for fermentable sugars, and to develop high efficiency pretreatment and saccharification of Miscanthus. The M. sinensis Shiozuka from wild populations grown in Japan, and $\mathrm{M} \times \mathrm{G}$ were cultivated in Sapporo in Japan, and harvested materials were used. The components of these samples were compared, and the ball milling (physical treatment) and alkaline-peroxide treatment (chemical treatment) of these samples were carried out and evaluated by enzymatic hydrolysis using commercial cellulase. Finally, a suitable enzyme was prepared for the enzymatic hydrolysis of Miscanthus by cultivating T. reesei and Penicillium pinophilum, which are cellulase-producing filamentous fungi.

\section{Materials and Methods}

2.1. M. sinensis Shiozuka and $\mathrm{M} \times \mathrm{G}$

M. sinensis Shiozuka, which were selected for high biomass- potential from various wild populations (Anzoua et al., 2011), and $\mathrm{M} \times \mathrm{G}$ were cultivated in Sapporo ( $43^{\circ} 04^{\prime} \mathrm{N}$, $141^{\circ} 20^{\prime}$ E), harvested in November 2011, and used for this study. The sample was 
manually cut to approximately $1-2 \mathrm{~cm}$, and pre-milled using ABSOLUTE3 (OSAKA CHEMICAL CO., Ltd., Osaka, Japan. Speed: High, VARIABLE: 0; 30 s). The premilled sample was air-dried at $60^{\circ} \mathrm{C}$ over night, and electrically sieved for $30 \mathrm{~min}$, and materials that were $125-500 \mu \mathrm{m}$ in size were selected as the starting material for pretreatment.

2.2 Ball milling (physical pretreatment)

Approximately $3 \mathrm{~g}$ of the starting material and $118 \mathrm{~g}$ of stainless steel balls were placed into a stainless vessel and ball milled at $400 \mathrm{rpm}(26.86 \times \mathrm{g})$ for $5-240 \mathrm{~min}$ in a freestar ball milling machine (Fritsch Japan Co., Yokohama, Japan).

\subsection{AHP treatment (chemical pretreatment)}

AHP treatment was performed using a modified method of previously published reports (Banerjee et al., 2012; Gould, 1985).The 5 mL-mixture of sodium hydrate aq. (0.25 -2 M) and hydrogen peroxide (0.3 -6 M) was added to approximately $0.5 \mathrm{~g}$ of the starting material in a $50 \mathrm{ml}$ Erlenmeyer flask. This flask was shaken at $200 \mathrm{rpm}$ with an orbital shaker (TAITEC Co., Saitama, Japan) at $50{ }^{\circ} \mathrm{C}, 70{ }^{\circ} \mathrm{C}$ and $90{ }^{\circ} \mathrm{C}$ for $3-21 \mathrm{~h}$. All reaction conditions are listed in Table 1 . The treated sample was washed over night with flowing tap water, rinsed with distilled water, soaked in ethanol, and vacuum dried at 
$55{ }^{\circ} \mathrm{C}$ for more than $3 \mathrm{~h}$. The solid recovery (SR) rate and weight loss (WL) of AHPtreated samples were calculated as equations (1) and (2), respectively.

$\mathrm{SR}(\%)=\left[\mathrm{W}_{\mathrm{a}} / \mathrm{W}_{\mathrm{b}}\right] \times 100$

where $\mathrm{W}_{\mathrm{a}}$ indicate the dry weight of a sample after AHP-treatment, and $\mathrm{W}_{\mathrm{b}}$ indicate the dry weight of the original sample

$\mathrm{WL}(\%)=100-\mathrm{SR}$

2.4 Preparation of cellulase enzymes

The following 2 strains were used for the production of cellulase enzymes: T. reesei ATCC 66589 (PC-3-7) was purchased from American Type Culture Collections, and $P$. pinophilum (AB194281 in National Center for Biotechnology Information), which was isolated from the soil by Hideno (2005). Both strains were maintained on potato dextrose agar (PDA) plates. The culture and production of cellulase enzymes were performed using a modified version of a previously reported method (Hideno et al., 2012; Morikawa et al., 1985), and the medium composition was as follows: $5 \mathrm{~g} / \mathrm{L}$ microcrystalline cellulose (Wako chemical Co., Osaka, Japan), 0.5 g/L Yeast extract (Difco Co., New Jersey, USA), 1.0 g/L Bacto peptone (Difco Co.), 1.4 g/L $\left(\mathrm{NH}_{4}\right)_{2} \mathrm{SO}_{4}$, $2.0 \mathrm{~g} / \mathrm{L} \mathrm{KH}_{2} \mathrm{PO}_{4}, 0.3 \mathrm{~g} / \mathrm{L} \mathrm{CaCl} 2 \cdot 2 \mathrm{H}_{2} \mathrm{O}, 0.3 \mathrm{~g} / \mathrm{L} \mathrm{MgSO}_{4} \cdot 7 \mathrm{H}_{2} \mathrm{O}, 1.0 \mathrm{~g} / \mathrm{L}$ Tween80, and 1.0 $\mathrm{g} / \mathrm{L}$ Trace element. The components of the trace elements were as follows: $0.06 \mathrm{~g} / \mathrm{L}$ 
$\mathrm{H}_{3} \mathrm{BO}_{3}, 0.26 \mathrm{~g} / \mathrm{L}\left(\mathrm{NH}_{4}\right)_{6} \mathrm{Mo}_{7} \mathrm{O}_{24} \cdot 4 \mathrm{H}_{2} \mathrm{O}, 1.00 \mathrm{~g} / \mathrm{L} \mathrm{FeCl}_{3} \cdot 6 \mathrm{H}_{2} \mathrm{O}, 0.40 \mathrm{~g} / \mathrm{L} \mathrm{CuSO} \cdot 5 \mathrm{H}_{2} \mathrm{O}$

$0.08 \mathrm{~g} / \mathrm{L} \mathrm{MnCl}_{2} \cdot 4 \mathrm{H}_{2} \mathrm{O}$, and $2.00 \mathrm{~g} / \mathrm{L} \mathrm{ZnCl}_{2}$. The appropriate amount of urea was

dissolved in distilled water and passed through a sterile $0.22-\mu \mathrm{m}$ microfilter (Millex

GV; Carrigtwohill, Cork, Ireland). The sterilized trace elements and urea were added to the medium before inoculation. Spores $\left(1 \times 10^{7}\right)$ were inoculated into $10 \mathrm{~mL}$ medium in a 100-mL Erlenmeyer flask, and the flask was incubated with shaking at $200 \mathrm{rpm}$ for 7 days at $30{ }^{\circ} \mathrm{C}$. At the end of the incubation period, the culture was centrifuged at 9,000 rpm for $15 \mathrm{~min}$, filtered through a sterile $0.45-\mu \mathrm{m}$ microfilter, and used for enzymatic hydrolysis. Cellulase activity in the culture filtrate was measured by the FPU assay (Ghose, 1987), whereas the protein concentration was measured by the bicinchoninic acid protein assay by using the BCA protein assay kit (Thermo Scientific Co., MA, USA) based on the method described by Smith et al. (Smith et al., 1985). The culture filtrate and commercial cellulase (Accellerase1500 [ACC1500]; Genencor Co., CA, USA) were diluted using $0.05 \mathrm{M}$ citrate buffer based on the protein concentration, and were used for the enzymatic hydrolysis of pretreated Miscanthus samples.

\subsection{Enzymatic hydrolysis of Miscanthus}

Enzymatic hydrolysis was performed as described previously (Hideno et al., 2009).

ACC 1500 and the culture filtrate of T. reesei ATCC 66589 were used as the main enzymes. The culture filtrate of $P$. pinophilum was used as accessory enzyme to that of 
T. reesei. The total enzyme concentration was $40 \mathrm{mg}$ protein/g substrate, and the mixed ratio of the main enzymes and accessory enzymes was 1:1 based on the amount of protein. The enzymatic reaction was performed at $45^{\circ} \mathrm{C}$ for $72 \mathrm{~h}$. The reaction mixture was centrifuged at 20,000 $\times \mathrm{g}$ for $10 \mathrm{~min}$, and the supernatant was diluted and applied to a high-performance liquid chromatography (HPLC, Jasco Co., Tokyo, Japan) system that was equipped with an HPX-87P column (7.8 mm ID, $30 \mathrm{~cm}$ length, Bio Rad, Hercules, USA) for sugar analysis. The column oven was set at $80{ }^{\circ} \mathrm{C}$, and samples were eluted at $1 \mathrm{~mL} / \mathrm{min}$ with water. The sugar yield was calculated using equation (3): Sugar yield $(\%)=\mathrm{a} \times \mathrm{SR} \times \mathrm{b}^{-1} \times \mathrm{c}^{-1}(3)$ where $\mathrm{a}, \mathrm{b}$, and c indicate the amount of produced sugar $(\mathrm{mg})$, dry weight of substrate (g), and monomeric sugar content of the original sample (mg sugar/g original weight), respectively.

2.5 Analysis of the constituent sugar and Klason lignin

The contents of structural carbohydrates and Klason lignin in Miscanthus samples were analyzed based on the method of the laboratory analytical procedure of the standard National Renewable Energy Laboratory (Sluiter et al., 2008). Samples (approximately $0.3 \mathrm{~g}$ ) were agitated in a tube rotator with $300 \mu \mathrm{L} 72 \%$ sulfuric acid for $1 \mathrm{~h}$ at room temperature. The mixture was diluted to $4 \%$ sulfuric acid with distilled water, autoclaved at $121{ }^{\circ} \mathrm{C}$ for $60 \mathrm{~min}$, and neutralized to $\mathrm{pH} 6.0-8.0$ with saturated $\mathrm{Ba}(\mathrm{OH})_{2}$ 
aq. The residual material was cooled, washed with $100 \mathrm{~mL}$ distilled water, and filtered through a glass filter using an aspirator. The solids were dried to a constant weight at $105^{\circ} \mathrm{C}$, and the dry weight of the solids was measured as the acid-insoluble lignin (Klason lignin) content. The neutralized solution was centrifuged at 20,000 $\times$ g for 10 min, and the supernatant was filtered through a $0.45-\mu \mathrm{m}$ filter. The neutral sugars (glucose, xylose, galactose, and mannose) in the filtrate were analyzed by HPLC as described above.

\section{Results and Discussion}

\subsection{Comparison of the main composition of Miscanthus}

M. sinensis Shiozuka was selected as the representative high biomass production $M$. sinensis, and was compared with $\mathrm{M} \times \mathrm{G}$ cultivated in 2011. The main components of $M$. sinensis Shiozuka and $\mathrm{M} \times \mathrm{G}$ cultivated in 2011 are shown in Table 2. The glucose content of Shiozuka cultivated in 2011 was lower and the Klason lignin content was slightly higher than the contents recorded in the 2010 cultivated line. $M \times G$ had higher glucose and Klason lignin contents than all other samples. In a previous study, $\mathrm{M} \times \mathrm{G}$ was more highly lignified than $M$. sinensis genotypes, but it had less hemicellulose content (Hodgson et al., 2010). Our results of $M \times G$ were consistent although the hemicellulose content recorded was different. In terms of calories, $\mathrm{M} \times \mathrm{G}$ is a promising energy grass and is suitable as a heat source by combustion. However, the high-lignin 
content in $\mathrm{M} \times \mathrm{G}$ may enhance recalcitrance and make hydrolysis difficult. In contrast, the chemical composition of $M$. sinensis showed that it contained moderate cellulose content and slightly lower lignin content; these observations were consistent with those of previous report (Serrano et al., 2010). The selected line of M. sinensis Shiozuka, was a promising feedstock because it produced more biomass than other grasses, and it had low -lignin content, which would result in high enzymatic digestibility.

\subsection{Enzymatic hydrolysis of physically pretreated Miscanthus}

The enzymatic hydrolysis process of ball milled M. sinensis Shiozuka and $\mathrm{M} \times \mathrm{G}$ is shown in Fig. 1. Both sugar yields of non-treated Shiozuka and $M \times G$ were low although their lignin contents were different. The glucose and xylose yields from Shiozuka gradually increased with a ball milling time, significantly increased more than 30 min of ball milling time, and plateaued with more than 60 min of ball milling. On the other hand, glucose and xylose yields from $\mathrm{M} \times \mathrm{G}$ were low with 30 min of ball milling, increased with more than 60 min of ball milling, and were similar to those of Shiozuka at 120 min of ball milling. Our result indicated that Shiozuka was more fragile and sensitive to physical treatment such as ball milling, and it was more easier to hydrolyze than $\mathrm{M} \times \mathrm{G}$ although the content of cellulose in $M$. sinensis was lower than that in $\mathrm{M} \times \mathrm{G}$. In other words, the results illustrated in Fig. 1 can be explained by the relatively lower level of lignin and the fewer crosslinks between lignin and polysaccharides in Shiozuka. 
Shiozuka has the potential to be used as a resource for obtaining fermentable sugars with energy consumption lower than that of $\mathrm{M} \times \mathrm{G}$, although the sugar contents in Shiozuka were slightly lower than those in $M \times G$.

\subsection{Composition of chemically pretreated Miscanthus}

The relationship between the SR and the major components (glucose, xylose, and Klason lignin content) of chemically treated Miscanthus is shown in Fig. 2. AHP treatment was performed as a chemical pretreatment, and the same conditions were used same for both samples (Shiozuka and $\mathrm{M} \times \mathrm{G}$ ). In many cases, the SR of Shiozuka was lower than that of $\mathrm{M} \times \mathrm{G}$ although the conditions of the AHP-treatment were the same. There was negative correlation between the SR and glucose content derived from cellulose, whereas the lignin contents and SR had a positive correlation. The xylose had the optimum SR of approximately $80 \%$. Sun et al. (2000) reported that the AHP treatment of rice straw enhanced the dissolution of hemicellulose with a large molecular size, which is rich in xylose. Our results showed that the main components of the soluble fraction of AHP-treated Miscanthus were lignin and xylan. Especially, the hemicellulose and lignin in Shiozuka were more easily decomposed by AHP treatment than those in $\mathrm{M} \times \mathrm{G}$, and the cellulose content of AHP-treated Shiozuka was higher than that of $M \times G$. It is easier to remove the lignin in Shiozuka than that in $M \times G$ by AHP 
treatment. Shiozuka was more sensitive to the chemical pretreatment and had higher cellulose content than that in $\mathrm{M} \times \mathrm{G}$.

\subsection{Enzymatic digestibility of chemically pretreated Miscanthus}

The relationship between the Klason lignin content (\%) and enzymatic digestibility of AHP-treated Miscanthus is shown in Fig. 3. The correlation between the Klason lignin and glucose yield was significantly negative. Weight loss in AHP-treated Miscanthus was mainly attributed to the removal of Klason lignin and hemicellulose. In other words, high weight loss from the AHP treatment was because of low lignin content, and this resulted in a high glucose yield in the enzymatic hydrolysis process. Using the same AHP-treatment conditions (Table 1), we observed a general trend of consistently higher glucose yields of Shiozuka compared with those of $\mathrm{M} \times \mathrm{G}$. There were differences in the correlations between Klason lignin and the glucose yield in Shiozuka and $\mathrm{M} \times \mathrm{G}$, although both correlations were negative. The glucose yield of Shiozuka significantly increased with less than $15 \%$ of Klason lignin, and reached its maximum. Li et al. (2012) described the existence of a "threshold" value for lignin removal that is necessary for either enzyme/water penetration into the cell wall or improved access into the cell wall by removing lignin that inhibits access to the cellulose. The lignin content at which they observed the rapid change in the glucan digestibility slope was in the range of $10 \%-15 \%$ in the AHP-treated corn stovers. These tendencies and values were 
similar to our results of $M$. sinensis. The amount and structure of lignin that covers and inhibits access to cellulose may be similar in other grasses. On the other hand, the glucose yields of $\mathrm{M} \times \mathrm{G}$ linearly increased with a decreasing Klason lignin content. The relationships between the xylose yield and Klason lignin were similar with respect to the glucose yield, although the slight differences in the xylose yields from Shiozuka and $M \times G$ were observed. In summary, Shiozuka was more sensitive to chemical treatments such as an AHP treatment than $\mathrm{M} \times \mathrm{G}$, and AHP-treated Shiozuka had higher enzymatic digestibility than AHP-treated $\mathrm{M} \times \mathrm{G}$.

Hydrogen peroxide is decomposed, and the perhydroxyl anion $\left(\mathrm{HOO}^{-}\right)$, a strong nucleophile, and other radical species $\left(\mathrm{HO} \cdot \mathrm{O}_{2}{ }^{-}\right)$are generated under alkaline conditions. The aryl ether bonds and other linkages in lignin are broken extensively by this anion and radical species (Xiang and Lee, 2000). The AHP treatment was thought to have caused the significant cleavage of $\beta-\mathrm{O}-4$ bonds, which occupy approximately $50 \%$ of all chemical bonds in lignin, and/or induce the lignin condensation reaction $(\mathrm{Li}$ et al., 2012).

The ester bridge is greatly cleaved by alkaline treatment. The differences in the sensitivity to AHP treatment between Shiozuka and $M \times G$ may be attributed to the numbers of this ester bridge. Considering previous reports and our results of ball milling and AHP treatment, not only the slightly lower content of lignin but also the lower numbers of ester bonds between lignin and polysaccharides via ferulic acid are 
suggested as the reasons why Shiozuka was more sensitive to ball milling and AHP treatment than $\mathrm{M} \times \mathrm{G}$.

The enzymatic digestibility could be correlated with the total lignin content and the content of p-hydroxycinnamates. Yoshida et al. (2008) indicated that lignin is the most significant resistance factor during enzymatic hydrolysis of normal $M$. sinensis, and some lignin might bind strongly to cellulose in chemically pretreated $M$. sinensis using the sodium chlorite delignification method, which inhibits cellulase activity. Our data showed that increasing of delignification led to increasing glucose yield in the enzymatic hydrolysis of AHP-treated Miscanthus. However, the glucose yields of BMtreated Miscanthus were also high, although almost the entire lignin content remained. Hence, we suggest that lignin does not cause the most significant resistance, and that the presence of some form of lignin cause the significant problem during enzymatic hydrolysis. Considering our data and those of previous studies, the lignin content that strongly binds to cellulose in Shiozuka may be less than that in $\mathrm{M} \times \mathrm{G}$, irrespective of whether the strong binding is direct.

\subsection{Enzymatic hydrolysis of AHP-treated Miscanthus by self-prepared cellulase} enzymes

ACC1500 was used as the representative commercial cellulase in this study because it is a suitable enzyme for the hydrolysis of chemically pretreated lignocelluloses, such as 
organosolv-treated (Hideno et al., 2013). The glucose yield of Shiozuka obtained using ACC1500 was higher than that of $\mathrm{M} \times \mathrm{G}$, although the xylose and arabinose yields were almost similar (Fig. 4). The on-site production or self-preparation of cellulases has been proposed as a cost-effective method (Fujimoto et al., 2008; Hideno et al., 2012). The glucose yields of Shiozuka and $\mathrm{M} \times \mathrm{G}$ obtained using the enzyme from a culture of $T$. reesei ATCC 66589 were similar and lower than those obtained using ACC1500; however, relative higher yields of xylose and arabinose were obtained. Hemicellulase of ACC1500, such as xylanase and arabinofuranosidase are considered to be lower than those of the enzymes obtained from the culture of T. reesei ATCC 66589. ACC1500 may be prepared from genetically engineered $T$. reesei by using the upstream promoter region of xylanase and arabinofuranosidase. Using the enzyme isolated from a mixed culture of T. reesei ATCC 66589 and P.pinophilum that was isolated by soil (Hideno, 2005), the glucose yields of both Shiozuka and $M \times G$ increased to the same value as was obtained using ACC1500. Moreover, the yields of xylose and arabinose were higher than those obtained using ACC1500, although the arabinose yields were slightly lower than those obtained using the T. reesei ATCC 66589 enzyme. Our results indicate that it was possible to obtain high enzymatic digestibility from not only AHP-treated Shiozuka but also AHP-treated $\mathrm{M} \times \mathrm{G}$ by using a mixed culture of T. reesei ATCC 66589 and $P$. pinophilum as the cellulase enzyme. $\beta$-glucosidase is one of the most widely reported synergistic effects of the cellobiohydrolase from T. reesei (Zhang et al., 2006). Selig et 
al. reported that the addition of xylanolytic enzymes generally enhanced the performance of the cellobiohydrolase from $T$. reesei on pretreated biomass, and the xylan fraction more directly occluded the cellulose in pretreated lignocelluloses and showed higher cellulase activity (Selig et al., 2008, 2009). Furthermore, the addition of the xylanolytic enzyme and $\beta$-glucosidase are very important for enhancing the performance of the cellobiohydrolase from $T$. reesei on the pretreated biomass. The specific xylanolytic enzyme in the T. reesei ATCC 66589 culture was higher than that in the ACC1500 commercial cellulase although the specific activity of the Filter degrading enzyme of ACC1500 was higher than that of the cultures. The specific activity of $\beta$-glucosidase in the culture of $P$. pinophilum was higher than that in the $T$. reesei ATCC 66589 culture. Moreover, the combination of the T. reesei ATCC 66589 and $P$. pinophilum cultures was suitable for enzymatic hydrolysis of AHP-treated Miscanthus because xylanolytic enzymes and $\beta$-glucosidase show synergistic effects on cellobiohydrolase.

\section{Conclusion}

To determine the efficiencies of pretreatment and enzymatic digestibility of Miscanthus, the chemical composition and the efficiency of ball milling and AHP treatment for enzymatic hydrolysis were compared in the 3 selected lines of $M$. sinensis and $\mathrm{M} \times \mathrm{G}$. Moreover, suitable cellulases were prepared for the enzymatic hydrolysis of AHP- 
treated Miscanthus. Shiozuka, which showed the highest biomass production in Sapporo, was a promising feedstock material for obtaining fermentable sugar by enzymatic hydrolysis. Further it was possible to increase sugar yield in enzymatic hydrolysis of AHP-treated $\mathrm{M} \times \mathrm{G}$ sample with same level of Shiozuka by using suitable self-prepared enzymes cocktail.

\section{Acknowledgements}

This work was supported by the Shorai Foundation for Science and Technology, and by JSPS KAKENHI Grant-in-Aid for Young Scientist (B) (Grant No. 22780292). The authors thank Dr. Seiya Watanabe (Ehime University) for supplying the commercial enzyme. 


\section{References}

1. Anzoua, K.G., Kajihara, Y., Toma, Y., Iizuka, N., Yamada, T., 2011. Potentiality of four cool season grasses and Miscanthus sinensis for feedstock in the cool regions of Japan. J. Jpn. Inst. Energy 90, 59-65.

2. Banerjee, G., Car, S., Liu, T., Williams, D.L., Meza, S.L., Walton, J.D., Hodge, D.B., 2012. Scale-up and integration of alkaline hydrogen peroxide pretreatment, enzymatic hydrolysis, and ethanolic fermentation. Biotechnol. Bioeng. 109, 922931.

3. Brosse, N., Dufour, A., Meng, X., Sun, Q., Ragauskas, A., 2012. Miscanthus: a fastgrowing crop for biofuels and chemicals production. Biofuels Bioprod. Bioref. 6, 580-598.

4. Christian, D.G., Riche, A.B., Yates, N.E., 2008. Growth, yield and mineral content of Miscanthus $\times$ giganteus grown as a biofuel for 14 successive harvests. Ind. Crops Prod. 28, 320-327.

5. Clifton-Brown, Renvoize, S., Chiang, Y.-C., Ibaragi, Y. Flavell, R., Greef, J., Huang, L., Hsu, T. W., Kim, D.-S., Hastings, A., Schwarz, K., Stampfl, P., Valentine, J., Yamada, T., Xi, Q., Donnison, I., 2011. Developing Miscanthus for Bioenergy. In: Energy Crops (Eds. N.G. Halford, A. Karp), Royal Society of Chemistry, Cambridge, pp 301-321. 
6. Fujimoto, S., Inoue, H., Yano, S., Sakaki, T., Minowa, T., Endo, T., Sawayama, S., Sakanishi, K., 2008. Bioethanol production from lignocellulosic biomass requiring no sulfuric acid: mechanochemical pretreatment and enzymic saccharification. J. Japn. Petrol. Inst. 51, 264-273.

7. Ghose, T. K., 1987. Measurement of cellulase activities. Pure Appl. Chem. 59, 257268.

8. Gould, J.M., 1984. Enhanced polysaccharide recover from agricultural residues and perennial grasses treated with alkaline hydrogen peroxide. Biotechnol. Bioeng. 27, 893-896.

9. Gould, J.M., 1985. Enhanced polysaccharide recovery from agricultural residues and perennial grasses treated with alkaline hydrogen peroxide. Biotechnol. Bioeng. 27, 893-896.

10. Heaton, E. A., Dohleman, F. G., Miguez, A. F., Juvik, J. A., Lozovaya, V., Widholm, J. M., Zabotina, O. A., McIsaac, G. F., David, M. B., Voigt, T. B., Boersma, N. N., Long, S. P., 2010. Miscanthus: A Promising Biomass Crop. Adv. Bota. Res. 56, 75-137.

11. Hideno, A., Inoue, H., Tsukahara, K., Fujimoto, S., Minowa, T., Inoue, S., Endo, T., Sawayama, S.,2009. Wet disk milling pretreatment without sulfuric acid for enzymatic hydrolysis of rice straw. Bioresour. Technol. 100, 2706-2711. 
12. Hideno, A., Inoue, H., Tsukahara, K., Yano, S., Fang, X., Endo, T., Sawayama, S., 2012. Production and characterization of cellulases and hemicellulases by Acremonium cellulolyticus using rice straw subjected to various pretreatments as the carbon source. Enz. Microb. Technol. 48, 162-168.

13. Hideno, A., Kawashima, A., Endo, T., Honda, K., Morita, M., 2013. Ethanol-based organosolv treatment with trace hydrochloric acid improves the enzymatic digestibility of Japanese cypress (Chamaecyparis obtusa) by exposing nanofibers on the surface. Bioresour. Technol. 132, 64-70.

14. Hodgson, E.M., Lister, S.J., Bridgwater, A.V., Brown, J.C., Donnison, I.S., 2010. Genotype and environmentally derived variation in the cell wall composition of Miscanthus in relation to its use as a biomass feedstock. Biomass Bioenergy 34, $652-660$.

15. Hodkinson, T.R., Renvoize, S., 2001. Nomenclature of Miscanthus $\times$ giganteus (Poaceae). Kew. Bulletin. 56, 759-760.

16. Huang, J., Xia, T., Li, A., Yu, B., Li, Q., Tu, Y., Zhang, W., Yi, Z., Peng, L., 2012. A rapid and consistent near infrared spectroscopic assay for biomass enzymatic digestibility upon various physical and chemical pretreatments in Miscanthus. Bioresour. Technol. 121, 274-281. 
17. Huyen, T.L., Remond, C., Dheilly, R.M., Chabbert, B., 2010. Effect of harvesting date on the composition and saccharification of Miscanthus $\times$ giganteus. Bioresour. Technol. 101, 8224-8231.

18. Kim, S.J., Kim, M.Y., Jeong, S.J., Jang, M.S., Chung, I.M., 2012. Analysis of the biomass content of various Miscanthus genotypes for biofuel production in Korea. Ind. Crops Prod. 38, 46-49.

19. Lewandowski, I., Scurlock, J. M. O., Lindvall, E., Christou, M., 2003. The development and current status of perennial rhizomatous grasses as energy crops in the US and Europe. Biomass Bioenergy 25, 335-361.

20. Li, M., Foster, C., Kelkar, S., Pu, Y., Holmes, D., Ragauskas, A., Saffron, C., Hodge, D.B., 2012. Structual characterization of alkaline hydrogen peroxide pretreated grasses exhibiting diverse lignin phenotypes. Biotechnol. Biofuel. 5, 38.

21. Monte, J.R., Brienzo, M., Milagres, A.M.F., 2011. Utilization of pineapple stem juice to enhance enzyme-hydrolytic efficiency for sugarcane baggase after an optimized pre-treatment with alkaline peroxide. Appl. Energ. 88, 403-408.

22. Morikawa, Y., Kawamori, M., Ado, Y., Shinsha, Y., Oda, F., Takasawa, S., 1985. Improvement of cellulase production in Trichoderma reesei. Agric. Biol. Chem. 49, $1869-1871$. 
23. Naidu, S.L., Long, S.P., 2004. Potential mechanisms of low-temperature tolerance of C4 photosynthesis in Miscanthus xgiganteus: an in vivo analysis. Planta 220, $145-155$.

24. Selig, M.J., Knoshaug, E.P., Adney, W.S., Himmel, M.E., Decker, S.R., 2008. Synergistic enhancement of cellobiohydrolase performance on pretreated corn stover by addition of xylanase and esterase activities. Bioresour. Technol. 99, 49975005.

25. Selig, M.J., Vinzant, T.B., Himmel, M.E., Decker, S.R., 2009. The effect of lignin removal by alkaline peroxide pretreatment on the susceptibility of corn stover to purified cellulolytic and xylanolytic enzymes. Appl. Biochem. Biotechnol. 155, $397-406$

26. Serrano, L., Egues, I., Gonzalez Alriols, M., Liano-Ponte, R., Labidi, J., 2010. Miscahus sinensis fractionation by different reagents. Chem. Eng. J. 156, 49-55.

27. Sluiter, A., Hames, B., Ruiz, R., Scarlata, C., Sluiter, J., Templeton, D., Crocker, D., 2008. Determination of structural carbohydrates and lignin in biomass. Laboratory analytical procedure (LAP). Technical report NREL/TP-510-42618.

28. Smith, P.K., Krohn, R.I., Hermanson, G.T., Malia, A.K., Gatner, F.H., Provenzano, M.D., Fujimoto, .K., Goeke, N.M., Olson, B.J., Klenk, D.C., 1985. Measurement of protein using bicinchoninic acid. Anal. Biochem. 150, 76-85. 
29. Stewart, J.R., Toma, Y., Ferandez, F.G., Nishiwaki, A., Yamada, T., Bollero, G., 2009. The ecology and agronomy of Miscanthus sinensis, a species important to bioenergy crop development, in its native range in Japan: a review. Glob. Change Biol. Bioenergy 1, 126-153.

30. Sun, R.C., Tomkinson, J., Ma, P.L., Liang, S.F., 2000. Comparative study of hemicelluloses from rice straw by alkali and hydrogen peroxide treatments. Carbohydr. Polym. 42, 111-122.

31. Wang, B., Wang, X., Feng, H., 2010. Deconstructing recalcitrant Miscanthus with alkaline peroxide and electrolyzed water. Bioresour. Technol. 101, 752-760.

32. Xiang, Q., Le, Y.Y., 2000. Oxidative cracking of precipitated hardwood lignin by hydrogen peroxide. Appl. Biochem. Biotechnol. 84-86, 153-162.

33. Yoshida, M., Liu, Y., Uchida, S., Kawarada, K., Ukagami, Y., Ichinose, H., Kaneko, S., Fukuda, K., 2008. Effects of cellulose crystallinity, hemicellulose, and lignin on the enzymatic hydrolysis of Miscanthus sinensis to monosaccharides. Biosci. Biotechnol. Biochem. 72, 805-810.

34. Zhang, Y.H.P., Himmel, M.E., Mielenz, J.R., 2006. Outlook for cellulase improvement: screening and selection strategies. Biotechnol. Adv. 24, 452-481. 


\section{Figure captions}

Figure 1 Comparison of the enzymatic hydrolysis of ball-milled Miscanthus

(a) and (b) represent the glucose yield (\%) and xylose yield (\%), respectively, in the enzymatic hydrolysis of ball -milled Miscanthus. Open and closed symbols denote Miscanthus sinensis Shiozuka, and Miscanthus $\times$ giganteus $(\mathrm{M} \times \mathrm{G})$, respectively. Circles and triangles denote glucose and xylose yields, respectively.

Figure 2 Relationships between solid recovery and main components in the alkaline-peroxide treated Miscanthus-samples

(a), (b), and (c) represent glucose content ( $\mathrm{mg} / \mathrm{g}$-residue), xylose content ( $\mathrm{mg} / \mathrm{g}$-residue), and percentage of Klason lignin (\%), respectively, in AHP-treated residues. Open and closed symbols denote Miscanthus sinensis Shiozuka, and $\mathrm{M} \times \mathrm{G}$, respectively. Circles, triangles and diamonds denote glucose content (mg glucose/g substrate), xylose content (mg-xylose/g-material), and Klason lignin content (\%), respectively.

Figure 3 Relationships between Klason lignin contents and enzymatic digestibilities in the alkalineperoxide treated Miscanthus-samples (a) and (b) represent glucose yield (\%) and xylose yield (\%), respectively, in the enzymatic hydrolysis of AHP-treated Miscanthus. Open and closed symbols denote Miscanthus sinensis Shiozuka and M×G, respectively. Circles and triangles denote glucose and xylose yields, respectively. 
Figure 4 Enzymatic hydrolyses of the alkaline-peroxide treated Miscanthus-samples by using commercial enzyme and prepared enzymes from Trichoderma reesei ATCC 66589 and Penicillium pinophilum White, white light gray, and dark gray bars represent glucose, xylose, and arabinose yields, respectively. ACC1500-40 mean the enzymatic hydrolysis using accellelase 1500 (40 mg protein/g substrate). Tr-40 mean the enzymatic hydrolysis using the filtrate culture of T. reesei ATCC 66589 (40 mg protein/g substrate). Tr-20+Pe-20 mean the enzymatic hydrolysis using the mixed culture of T. reesei ATCC 66589 (20 mg protein/g substrate) and $P$. pinophilum (20 mg protein/g substrate). 
Table 1 Conditions of alkaline-peroxide treatment of Miscanthus and solid recoveries (\%)

\begin{tabular}{|c|c|c|c|c|c|}
\hline Material & $\begin{array}{c}30 \% \mathrm{H}_{2} \mathbf{O}_{2} \\
(\mathrm{~mL})\end{array}$ & $\begin{array}{c}\text { 5M NaOH } \\
(\mathrm{mL})\end{array}$ & D.W. & $\begin{array}{c}\text { Temperature } \\
\left({ }^{\circ} \mathbf{C}\right)\end{array}$ & $\begin{array}{l}\text { SR } \\
(\%)\end{array}$ \\
\hline Shiozuka & - & - & - & - & 100 \\
\hline Shiozuka & 0.83 & 1.00 & 3.15 & 70 & 64 \\
\hline Shiozuka & 0.42 & 0.50 & 4.10 & 70 & 69 \\
\hline Shiozuka & 0.21 & 0.25 & 4.55 & 70 & 78 \\
\hline Shiozuka & 0.21 & 0.32 & 4.55 & 70 & 76 \\
\hline Shiozuka & 0.21 & 0.36 & 4.55 & 70 & 74 \\
\hline Shiozuka & 0.21 & 0.36 & 4.55 & 70 & 78 \\
\hline Shiozuka & 3.00 & 2.00 & 0.00 & 30 & 49 \\
\hline Shiozuka & 3.00 & 2.00 & 0.00 & 30 & 59 \\
\hline Shiozuka & 3.00 & 2.00 & 0.00 & 30 & 63 \\
\hline Shiozuka & 3.00 & 2.00 & 0.00 & 50 & 66 \\
\hline Shiozuka & 3.00 & 2.00 & 0.00 & 50 & 55 \\
\hline Shiozuka & 3.00 & 2.00 & 0.00 & 50 & 57 \\
\hline Shiozuka & 3.00 & 2.00 & 0.00 & 70 & 37 \\
\hline Shiozuka & 3.00 & 2.00 & 0.00 & 70 & 42 \\
\hline Shiozuka & 3.00 & 2.00 & 0.00 & 70 & 39 \\
\hline Shiozuka & 3.00 & 2.00 & 0.00 & 70 & 66 \\
\hline Shiozuka & 3.00 & 2.00 & 0.00 & 70 & 67 \\
\hline Shiozuka & 3.00 & 2.00 & 0.00 & 70 & 76 \\
\hline $\mathbf{M} \times \mathbf{G}$ & - & - & - & - & 100 \\
\hline $\mathbf{M} \times \mathbf{G}$ & 0.83 & 1.00 & 3.15 & 70 & 76 \\
\hline $\mathbf{M} \times \mathbf{G}$ & 0.42 & 0.50 & 4.10 & 70 & 76 \\
\hline $\mathbf{M} \times \mathbf{G}$ & 0.21 & 0.25 & 4.55 & 70 & 85 \\
\hline $\mathbf{M} \times \mathbf{G}$ & 0.21 & 0.32 & 4.55 & 70 & 83 \\
\hline $\mathbf{M} \times \mathbf{G}$ & 0.21 & 0.36 & 4.55 & 70 & 79 \\
\hline $\mathbf{M} \times \mathbf{G}$ & 0.21 & 0.36 & 4.55 & 70 & 83 \\
\hline $\mathbf{M} \times \mathbf{G}$ & 3.00 & 2.00 & 0.00 & 30 & 74 \\
\hline $\mathbf{M} \times \mathbf{G}$ & 3.00 & 2.00 & 0.00 & 30 & 75 \\
\hline $\mathbf{M} \times \mathbf{G}$ & 3.00 & 2.00 & 0.00 & 30 & 80 \\
\hline $\mathbf{M} \times \mathbf{G}$ & 3.00 & 2.00 & 0.00 & 50 & 77 \\
\hline $\mathbf{M} \times \mathbf{G}$ & 3.00 & 2.00 & 0.00 & 50 & 74 \\
\hline $\mathbf{M} \times \mathbf{G}$ & 3.00 & 2.00 & 0.00 & 50 & 75 \\
\hline $\mathbf{M} \times \mathbf{G}$ & 3.00 & 2.00 & 0.00 & 70 & 47 \\
\hline $\mathbf{M} \times \mathbf{G}$ & 3.00 & 2.00 & 0.00 & 70 & 48 \\
\hline $\mathbf{M} \times \mathbf{G}$ & 3.00 & 2.00 & 0.00 & 70 & 47 \\
\hline $\mathbf{M} \times \mathbf{G}$ & 3.00 & 2.00 & 0.00 & 70 & 89 \\
\hline $\mathbf{M} \times \mathbf{G}$ & 3.00 & 2.00 & 0.00 & 70 & 90 \\
\hline $\mathbf{M} \times \mathbf{G}$ & 3.00 & 2.00 & 0.00 & 70 & 90 \\
\hline
\end{tabular}

$\mathrm{M} \times \mathrm{G}$ denotes Miscanthus $\times$ giganteus. D.W. and SR denote distilled water and solid recovery, respectively. Samples with bars (-) indicate non-treated materials. 
Table 2 Constituent monomeric sugars and the percentage of Klason lignin in Miscanthus

\begin{tabular}{|c|c|c|c|c|}
\hline & \multicolumn{3}{|c|}{ mg sugar/g substrate } & \multirow{2}{*}{$\begin{array}{c}\% \\
\text { Klason lignin }\end{array}$} \\
\hline & Glucose & Xylose & Arabinose & \\
\hline Shiozuka-2011 & $359.9 \pm 9.9$ & $173.3 \pm 10.4$ & $42.1 \pm 4.2$ & $19.7 \pm 1.5$ \\
\hline $\mathrm{M} \times \mathrm{G}-2011$ & $419.8 \pm 14.5$ & $190.1 \pm 5.0$ & $41.4 \pm 4.2$ & $23.5 \pm 0.7$ \\
\hline
\end{tabular}


(a)

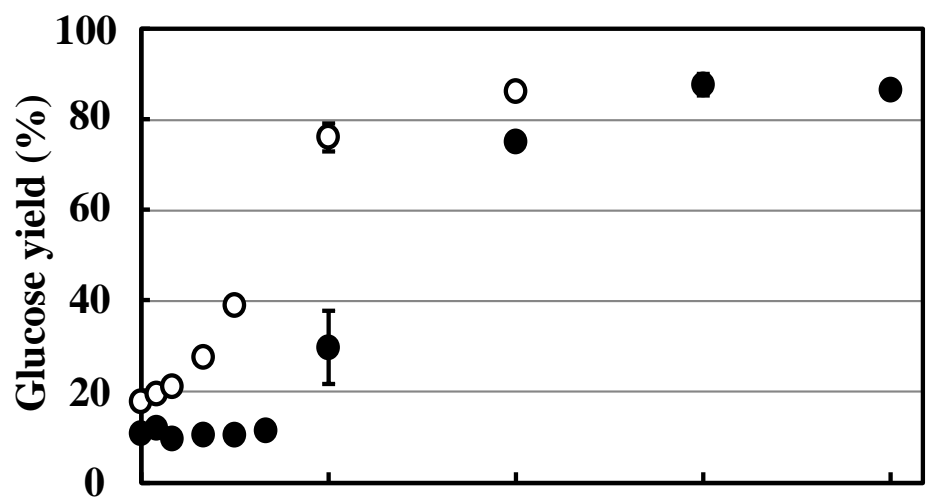

O : Shiozuka

: $: M \times G$

(b)

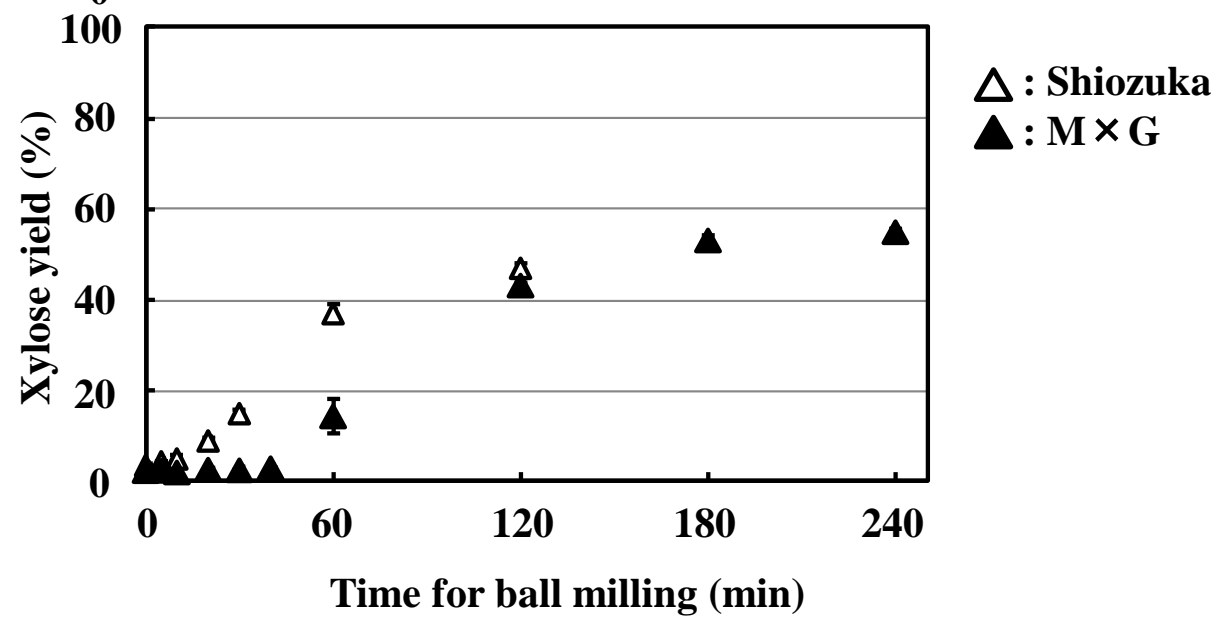

Fig. 1 Hideno et al. 
(a)

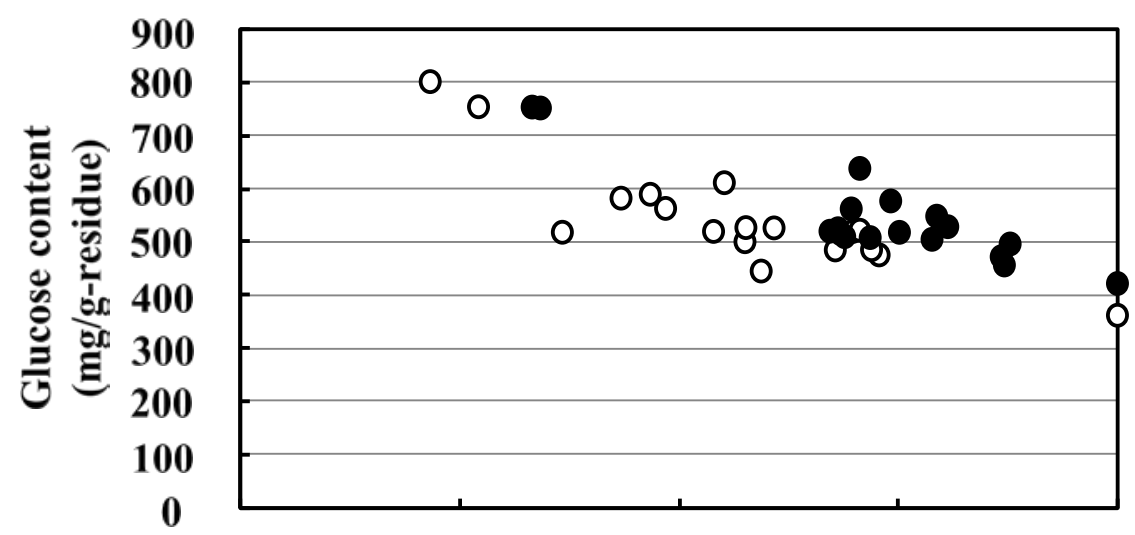

O : Shiozuka

: : $M \times G$

(b)

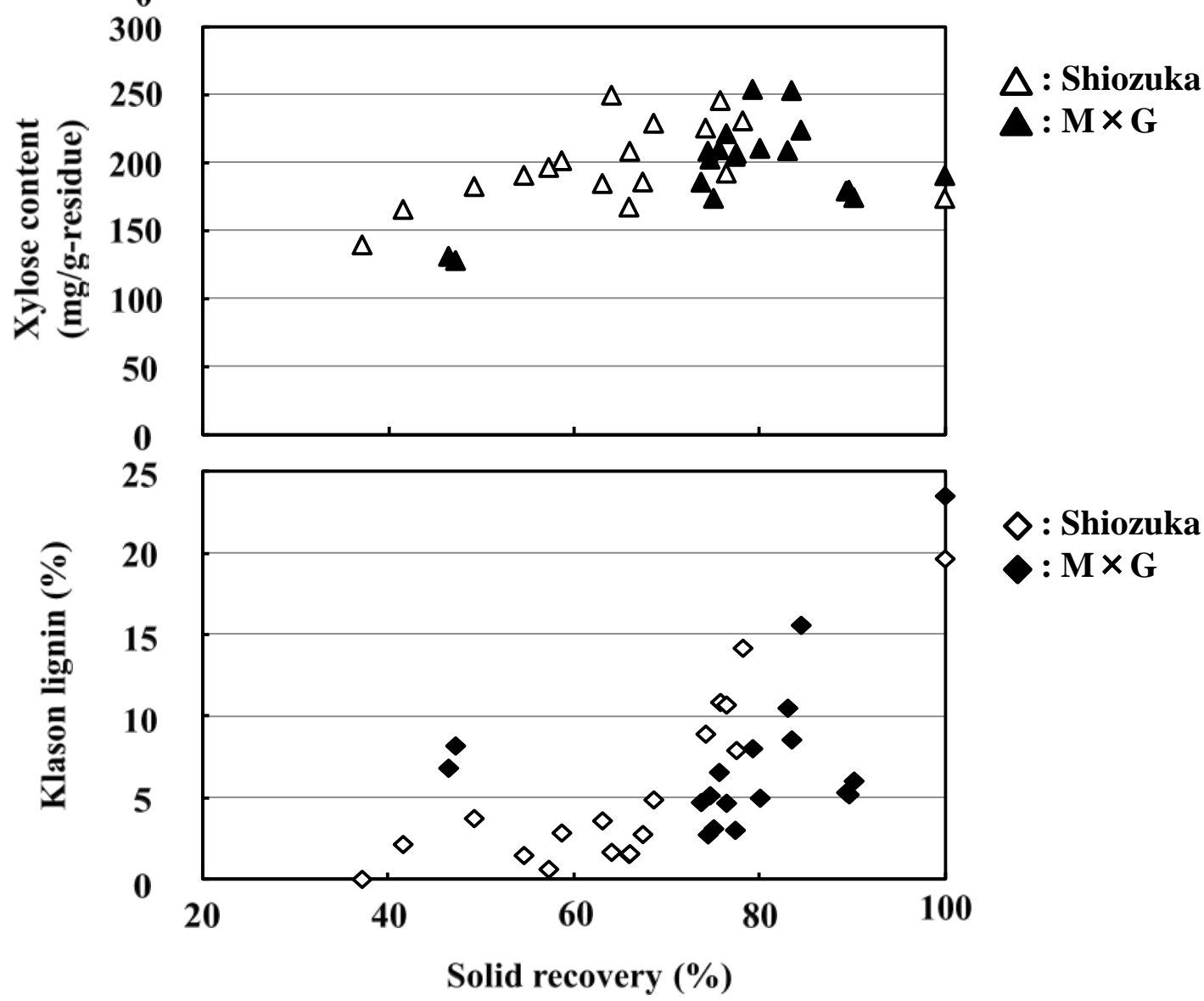

Fig. 2 Hideno et al. 
(a)

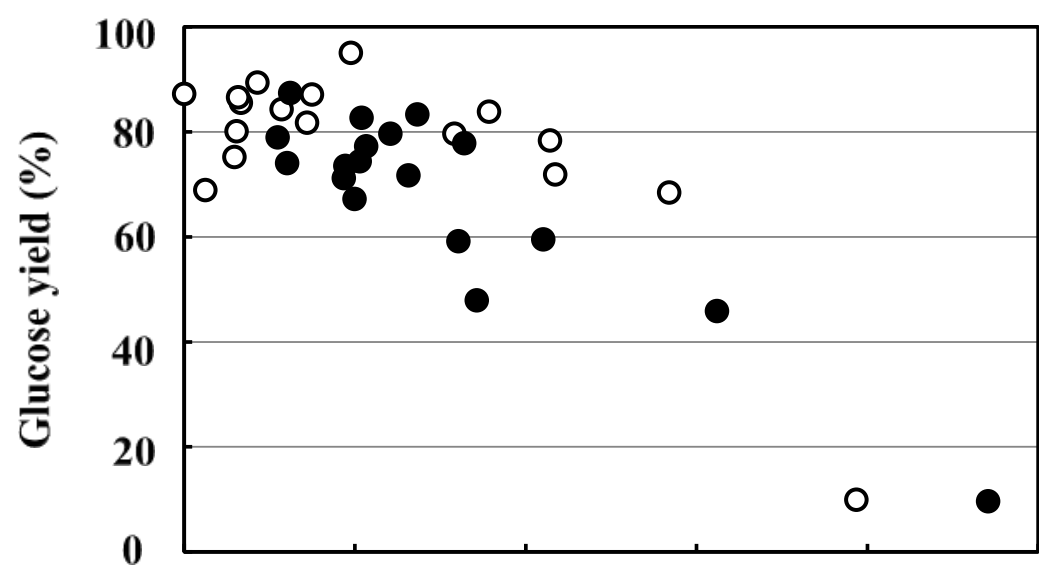

O : Shiozuka

: $\mathrm{M} \times \mathrm{G}$

(b)

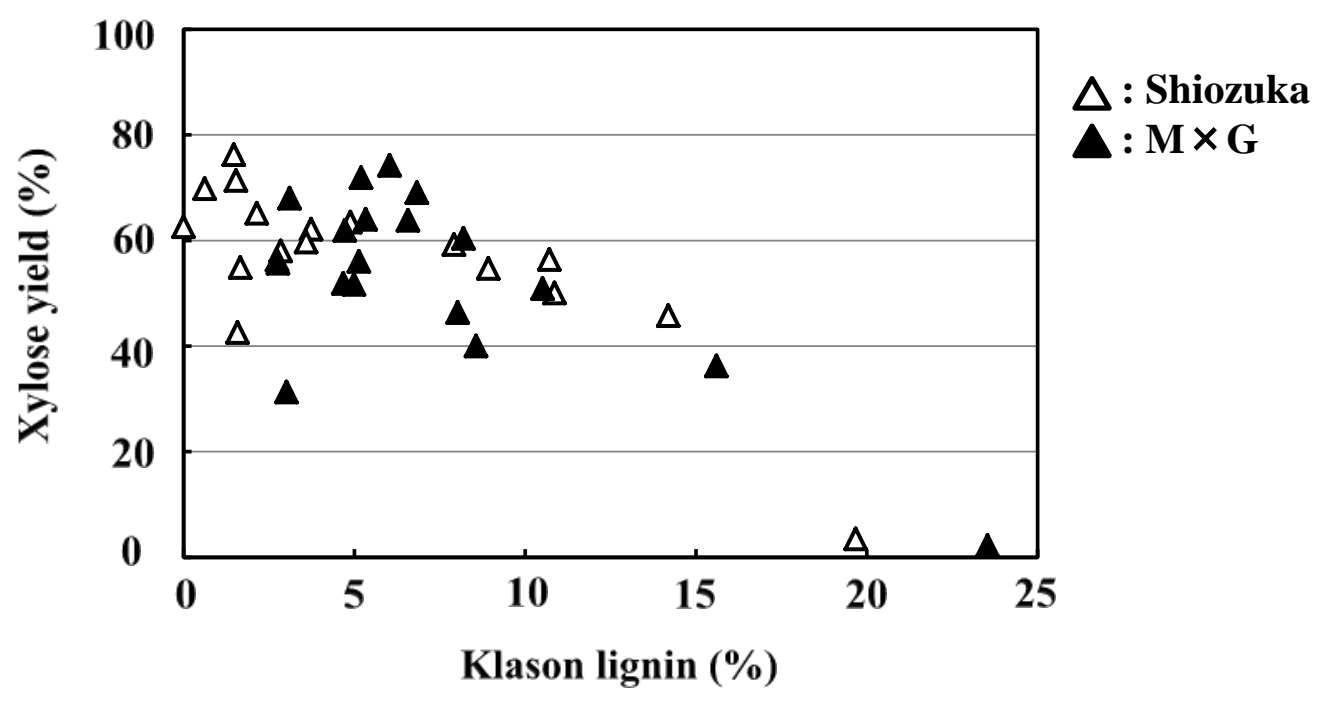

Fig. 3 Hideno et al. 


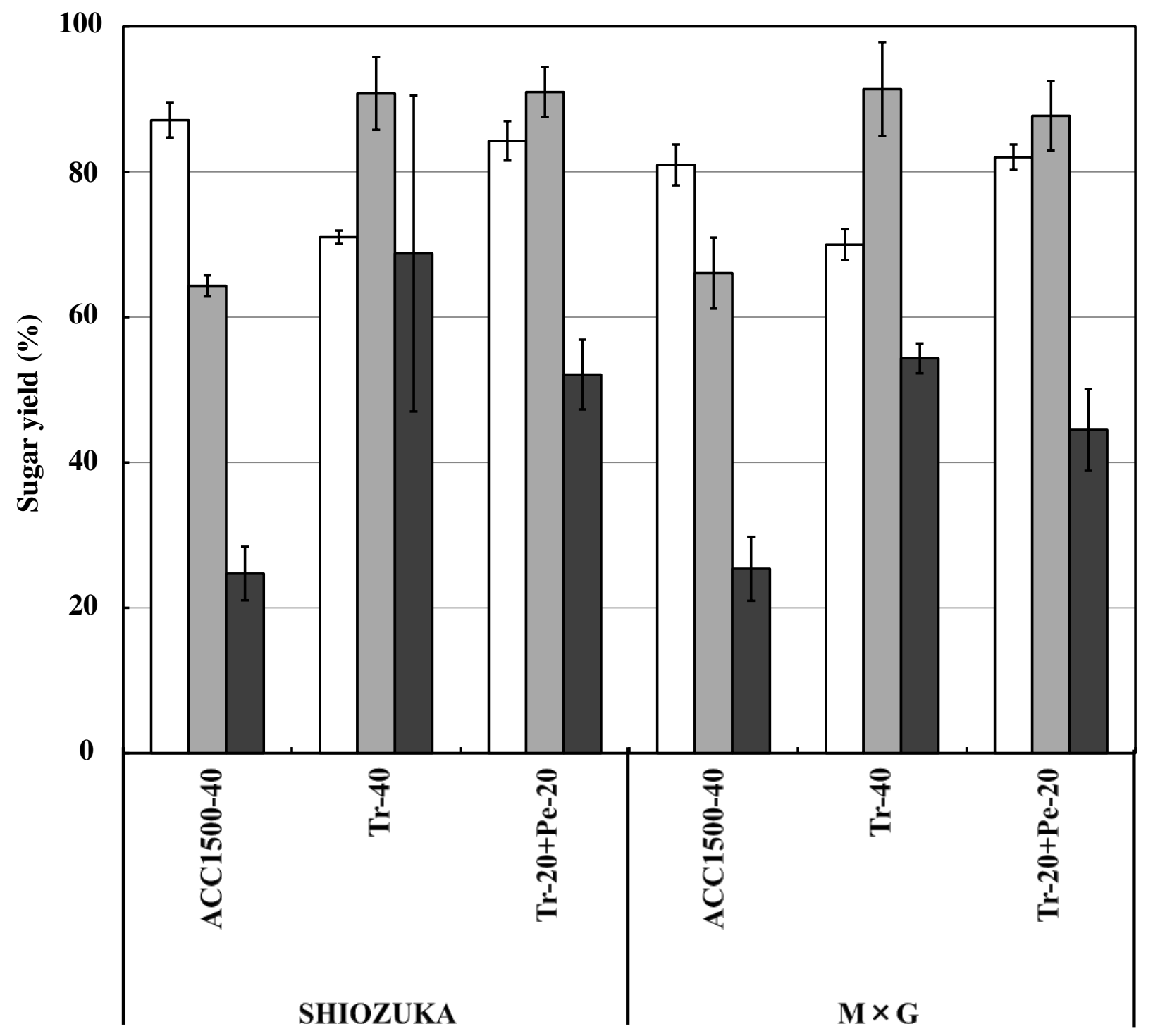

Fig. 4 Hideno et al. 